\section{Stand dynamics and natural regeneration in silver fir (Abies alba Mill.) plantations after traditional rotation age}

\author{
Francesca Bottalico, Davide Travaglini, Silvia Fiorentini, Chiara Lisa, \\ Susanna Nocentini
}

Most pure silver fir stands on the Apennine mountains (central Italy) originated from planting and were managed according to the traditional model, with clear cutting and a 100-years rotation. In the last decades, active management has stopped in most of these stands and management goals have changed towards nature conservation purposes. The aim of this work was: (1) to analyze stand dynamics and spontaneous regeneration processes taking place with increasing age in even-aged fir plantations; and (2) to discuss if the above processes may be useful for defining management approaches addressing such conservation purposes. The study was carried out in the Vallombrosa Forest (near Florence, Italy). The relationship between fir stand age and structural parameters was analyzed using inventory data. Gap dynamics were monitored between 1983 and 2007 based on remote sensing data. A field survey of a sample of gaps was carried out. Species composition and density of seedlings and saplings were analysed in relation to gap size and within-gap position. From 1983 to 2007 the number of gaps and their total area increased, following increasing stand age. Significant relationships $(p<0.01)$ were found between fir stand age and number of trees per hectare $(r=-0.30)$, quadratic mean diameter $(r=0.65)$ and volume per hectare $(r=0.50)$. A layer of trees with $\mathrm{DBH}<15 \mathrm{~cm}($ composed by 15 different broadleaf species usually mixed with fir) was observed in fir stands with lower stand density. Gap size influenced the presence of young firs (seedlings and fir $<0.5 \mathrm{~m}$ ), which were significantly more abundant in gaps $<200 \mathrm{~m}^{2}$, but it had relatively limited influence on species diversity. Withingap position did not affect the density of recruitments. Results indicate that the creation of small gaps $\left(<200 \mathrm{~m}^{2}\right)$ in the canopy cover may simulate the natural dynamics of aged fir plantations in the Apennines and may be considered as a possible management option for their gradual transformation into mixed, naturally regenerating forests.

Keywords: Abies Alba Mill., Plantations, Gap Dynamics, Natural Regeneration, Forest Biodiversity

\section{Introduction}

In the last decades forest management has shifted the focus from wood production to the provision of multiple environmental services and biodiversity conservation. Following this trend the conversion of forest plantations into naturally regenerating and more diverse and complex systems has become one of the aims of the sustainable forest

management, often trying to revert a process which had instead transformed vast areas of natural forests into plantations across Europe since the XIX century (Johann 2006, Bolte et al. 2007).

Silver fir (Abies alba Mill.) has frequently received attention from foresters and researchers, partly because there has been a long tradition of forest management in central and

$\square$ Department of Agriculture, Food and Forestry Systems, University of Florence, v. S. Bonaventura 13, I-50145, Florence (Italy)

@ Silvia Fiorentini (silvia.fiorentini@unifi.it)

Received: Mar 04, 2013 - Accepted: Dec 19, 2013

Citation: Bottalico F, Travaglini D, Fiorentini S, Lisa C, Nocentini S, 2014. Stand dynamics and natural regeneration in silver fir (Abies alba Mill.) plantations after traditional rotation age. iForest 7: 313-323 [online 2014-04-08] URL: http://www.sisef.it/iforest/ contents/? id=ifor0985-007

Communicated by: Emanuele Lingua southeast Europe in areas where the natural share of fir is significant (e.g., Kramer 1992, Brändli 1996), but mainly because of fir's economic, environmental and social significance. Signs of decline in fir presence have also been investigated (e.g., Elling et al. 2009, Ficko et al. 2011). Recently, Volarik \& Hedl (2013) suggested that periods of both decline and expansion have underpinned silver fir dynamics. While natural mixed beech-fir forests were largely converted to spruce plantations in central European mountains and in many Alpine areas (Johann 2007, Volarik \& Hedl 2013), in the Apennine Mountains (Italy) fir - naturally present in beech dominated mixed hardwood forests - was generally disfavoured by forest exploitation and has become relatively rare (Nocentini 2009). Today silver fir is an important species of five Natura 2000 habitats in the Apennines, three being priority habitats (*): 9130: Asperulo-Fagetum beech forests; 9210*: Apennine beech forests with Taxus and Ilex; 9220*: Apennine beech forests with Abies alba and beech forests with Abies nebrodensis; 9410: Acidophilous Picea forests of the montane to alpine levels ( Vaccinio-Piceetea); 9510*: Southern Apennine Abies alba.

Fir had often been preserved in small areas around monasteries, such as Vallombrosa and Camaldoli (Tuscan Apennines) where fir cultivation has been documented at least from the XVI century (Senni 1955, Gabbrielli 2003). Since late XVIII century fir planting started in various forests in the Tuscan Apennines, and this trend continued until the middle of the XX century. Most fir plantations are on State property and until the 1970s they were managed following the traditional model based on area regulation methods with clear cutting and 100 year rotation age (Vazzano et al. 2011, Bottacci et al. 2012).

In the 1970s and 1980s pure fir stands in the Apennines started showing symptoms which recalled fir decline and dieback observed in central Europe (Larsen 1986, Kandler \& Innes 1995), raising some concern about the future of this species. Together with these symptoms, Heterobasidion annosum (later identified as H. abietinum - Niemela \& Korhonen 1998) also caused some damage, consisting mainly in the death of individual or small groups of trees (Farina et al. 1990, Barzanti \& Capretti 1996, Capretti 1998).

At the end of the 1970s the State forests were declared Nature Reserves and management aims were reoriented towards multifunctionality and biodiversity conservation. Furthermore, in the last decades fir stands have gained increasing importance for their role in shaping a "cultural forest landscape" in these mountain areas (Ciancio \& Nocen- 


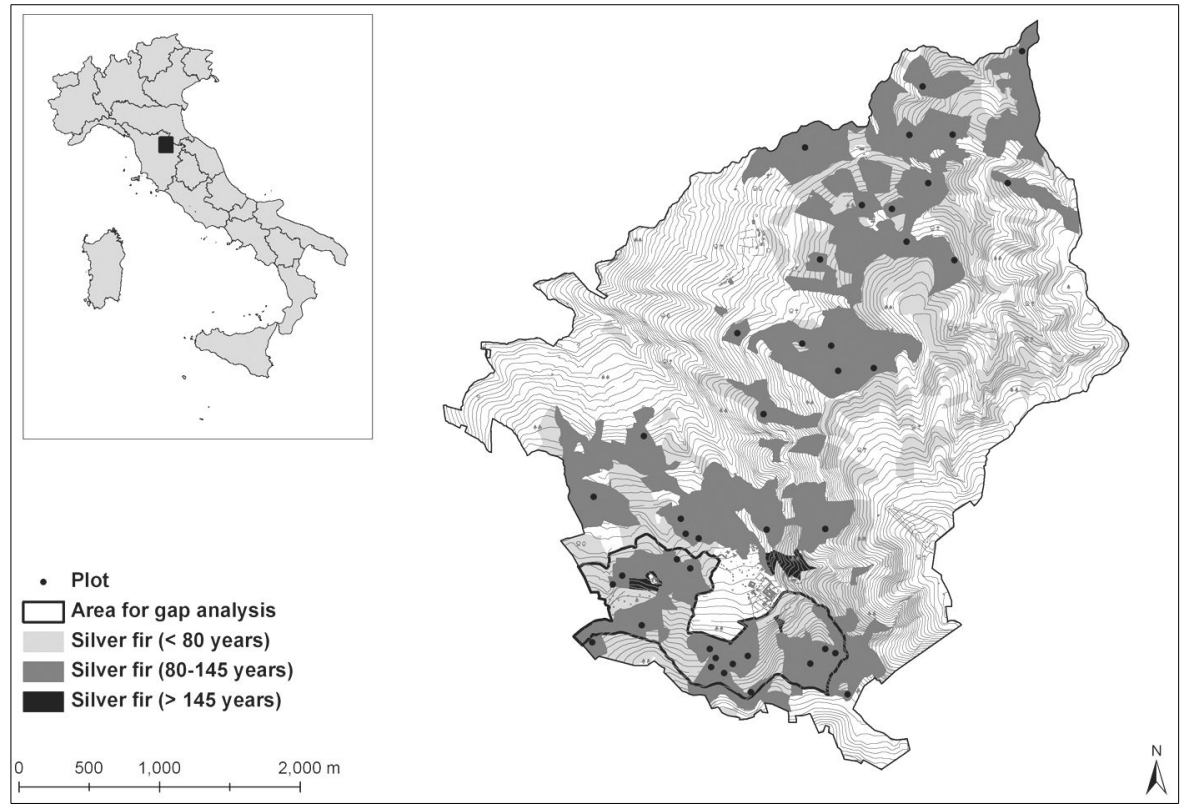

Fig. 1 - The Vallombrosa Forest. The area where gap analysis was carried out is outlined in black; black points show the 42 circular plots for stand structure analysis.

tini 2006).

Shifting from artificial to natural regeneration in pure even-aged fir stands has long been a matter of concern among silviculturists in Italy (Bianchi \& Paci 2008). In a field study in pure even-aged stands in the Vallombrosa State Forest, Magini (1967) showed that fir regeneration developed spontaneously along the edges of fir stands, while under dense stands or in large openings no fir regeneration was found. Nevertheless, results of this research were not transferred to the management level and the fir stands have evolved "naturally" for over 35 years. Only dead or dying trees were felled along forest roads for visitor safety (Ciancio \& Nocentini 2011, Bottacci et al. 2012).

Understanding how forest structure develops in response to natural disturbances is essential to evaluate current forest conditions in relation to management practices and conservation status (Attiwill 1994, Pham et al. 2004, Dobrowolska \& Veblen 2008, Puettmann et al. 2009, Seidl et al. 2011). The "gap phase" is considered important in forest regeneration by providing opportunities for tree recruitment, establishment and development (Watt 1947, Canham 1989, Runkle 1989, Peterken 1996, Brokaw \& Busing 2000, McCarthy 2001, Mountford et al. 2006, Baier et al. 2007). Gaps are also important in maintaining plant species diversity (Poulson \& Platt 1989, Busing \& White 1997, Brokaw \& Busing 2000, Degen et al. 2005). The size, shape, age and temporal changes of gaps influence the regeneration patterns of tree species, due to the different ecological traits of the particular tree species and to the effects on the herbaceous layer (e.g., Collins et al. 1985, Canham 1989, Poulson \& Platt 1989, Whitmore 1989, Denslow \& Spies 1990, Peterken 1996, Diaci 2002, Gálhidy et al. 2006, Diaci et al. 2012).

Many authors have examined the regeneration dynamics of conifer plantations as a basis for conversion towards mixed stands (e.g., Klimo et al. 2000, Diaci 2002, Zerbe 2002, Mansourian et al. 2005, Albanesi et al. 2008), but fewer studies have investigated these processes in relation to natural gap formation in this type of stands (e.g., Mattheus \& Ammer 2000, Kint 2005).

The aim of this work was: (1) to analyse stand dynamics and spontaneous regeneration processes that are taking place with increasing age in even-aged fir plantations, in particular following natural gap formation; and (2) to discuss if these processes can be useful for defining management approaches answering biodiversity conservation aims (e.g., Natura 2000).

\section{Material and methods}

\section{Study area}

Our research was carried out in fir stands growing in the Vallombrosa State Forest on the Apennine Mountains, $40 \mathrm{~km}$ east of the city of Florence $\left(43^{\circ} 43^{\prime}-43^{\circ} 46^{\prime} \mathrm{N}, 11^{\circ} 31^{\prime}\right.$ $-11^{\circ} 35^{\prime}$ E - Fig. 1).

The forest covers a total area of 1273 hectares between 470 and $1440 \mathrm{~m}$ a.s.l. on the western slope of Monte Secchieta (1447 $\mathrm{m}$ a.s.1.); over 600 ha are pure, even-aged fir stands.

The climate is temperate-humid with Mediterranean type rainfall with a summer mini- mum. Mean annual temperature is $9.7{ }^{\circ} \mathrm{C}$ and total annual rainfall is $1337 \mathrm{~mm}$, with an average of $71.2 \mathrm{~mm}$ in the summer months (June-August). Parent material is Oligocene sandstone of the "Macigno del Chianti" formation. The forest grows on sandy-loamy or loamy soils, rich in humus on the surface horizons. Soil depth varies. The slopes are generally steep or very steep.

In the past forest cover in the area was mainly chestnut and mesophilous oaks at intermediate altitudes and beech forests at higher elevation. Fir probably grew in small groups or mixed stands scattered throughout the forest, mostly within the beech area. The Vallombrosan (Benedictine) monks started fir cultivation in the XIV century (Gabbrielli 2000). In 1866 the Vallombrosa Forest was transferred to the Italian State Forestry administration. The first management plan for the Vallombrosa fir forest was drafted in 1876 , silviculture was based on clear cutting and artificial regeneration, with a 80 year rotation, and managed according to the age class area regulation method. This management model remained practically unchanged in the 7 following plans $(1886,1896,1923$, $1936,1949,1960,1970)$, the only change being rotation age which was increased to 100 years in 1896 . Total area covered by fir plantations in the forest increased from 217 ha in 1876 to 680 ha in 1960. Most fir plantations replaced beech forests (Bottalico et al. 2012).

In 1977 the Vallombrosa Forest was classified as a National Nature Reserve and is now included in the Site of Community Importance (SCI) "Vallombrosa and S. Antonio Forest" (IT5140012) under the Natura 2000 Network (Habitats Directive 92/43/EC). Two priority habitats $\left(9210^{*}\right.$ and $\left.9220^{*}\right)$ are included within the SCI. As a Nature Reserve, hunting is banned in the Vallombrosa Forest, and in the last decades wild ungulates are increasing in number and distribution (Apollonio et al. 2010), similarly to other areas in the northern Apennines. In the Vallombrosa Forest estimated densities of roe deer $(\mathrm{Ca}$ preolus capreolus L.), fallow deer (Dama dama L.) and wild boar (Sus scrofa L.) are very high: $13 \mathrm{ha}^{-1}$ have been estimated for fallow deer, which is at least 3 times greater than the estimated carrying capacity, and 27 $\mathrm{ha}^{-1}$ for wild boar, i.e., 6 times higher than the carrying capacity (Casanova et al. 2009).

\section{Data collection and analysis}

For stand structure analysis we selected all compartments which hosted pure silver fir stands with current age ranging from 80 to 145 years, according to the preceding management plans (Fig. 1). Forty-two $20 \mathrm{~m}$ radius circular plots $\left(1256 \mathrm{~m}^{2}\right)$ were randomly distributed in these compartments. In each plot we recorded species and diameter at $1.30 \mathrm{~m}$ (DBH) of all living trees with $\mathrm{DBH}>2.5$ 
$\mathrm{cm}$; we also measured total height on a sample of trees $(35 \%$ of trees in each $5 \mathrm{~cm} \mathrm{DBH}$ class).

Fir trees belonging to the original planted stands (aged 80 to 145 years in the different plots) were identified during the survey and recorded separately, so as to obtain a picture of the fir plantation development as compared to other species spreading naturally into the stands. Volume was estimated using a one entry volume table (Clauser 1950). Large trees with DBH $>50 \mathrm{~cm}$ and $>70 \mathrm{~cm}$ were analysed separately for their importance for biodiversity (Nilsson et al. 2002, Stokland et al. 2012). Linear regression models were used to determine the relationship between stand age, number of trees per hectare $(\mathrm{N})$, volume per hectare $(\mathrm{V})$ and quadratic mean diameter (QMD, diameter of the tree with average basal area). For each model the correlation coefficient $(r)$ was computed. Additionally, the relationship between density of the original fir stand (quantified by basal area per hectare, BA) and density of the lower stratum was investigated.

We monitored canopy gap dynamics over 103 hectares in the southern portion of the forest (Fig. 1). Since both VHR satellite images - an effective alternative to field surveys for canopy gap detection (Garbarino et al. 2012, Rugani et al. 2013) - and Airborne Laser Scanning data - useful for automatic gap detection over large areas (Zhang 2008 Barbati et al. 2009) - were not available in the study area, canopy gaps were monitored using multitemporal aerial remote sensing data. We used 1983 aerial photographs (flying height $750 \mathrm{~m}$ ), and 1997 and 2007 digital orthophotos with $1 \mathrm{~m}$ and $0.5 \mathrm{~m}$ pixel size, respectively. The 1983 images were scanned and orthorectified with $1 \mathrm{~m}$ pixel size $($ RMSE $=1$ pixel) using the OrTHOENGINE software package (PCI Geomatics, Richmond Hill, Ontario, Canada). Because no information about the camera was available, the Rational Functions Model was used (PCI 2001). To this purpose, a digital terrain model with a $5 \mathrm{~m}$ spatial resolution was created using contours extracted from topographic maps $(1: 10000)$ and ground control points were collected using the orthophotos as reference images.

Canopy openings $\geq 50 \mathrm{~m}^{2}$ were considered gaps. Such threshold was chosen since $50 \mathrm{~m}^{2}$ is the average crown projection area for fir trees in stands aged $100+$ years in similar areas of the Apennines (Travaglini et al. 2012). Gap margins were photointerpreted and digitized on-screen into a polygon layer on a GIS database. The following parameters were then calculated: number of gaps; total gap area; percent of total surveyed area covered by gaps (gap fraction); mean, standard deviation and maximum size of gaps for each survey year. We also examined the fate of the individual gaps, following the method proposed by Kenderes et al. (2008), i.e., creation of new gaps, gap closure, dissection of gaps and merging of neighbouring gaps. Because stereopairs were available only for the 1983 aerial photographs, we could not use the height of the vegetation filling the gap as an indication of gap closure (Runkle 1992, Pedersen \& Howard 2004). Therefore, a gap was classified as closed when its area was smaller than $50 \mathrm{~m}^{2}$ in the following orthophoto interpretation.

A field survey of the tree regeneration in all gaps $\geq 100 \mathrm{~m}^{2}$ located in stands $100+$ years and detected both in 1997 and 2007 was carried out, revealing 30 gaps matching the above characteristics. Number, height, species and impact by wild ungulates was recorded for all seedlings and saplings in 3 circular, 2m-radius plots $\left(12.56 \mathrm{~m}^{2}\right)$, placed along the major axis of the gap, one in the center, and the other two in the midpoint between the center and the gap margin. Each sampled individual was recorded in one of the following height classes: (i) one year-old seedlings; (ii) $<0.5 \mathrm{~m}$; (iii) $0.5-1 \mathrm{~m}$; (iv) $1-2$ $\mathrm{m}$; and $(\mathrm{v})>2 \mathrm{~m}$. Individuals were considered as impacted by wildlife when the leading stem and the branches showed clear signs of grazing.

We calculated the average number of individuals in each height class for the following gap size classes: (i) $<200 \mathrm{~m}^{2}$; (ii) $200-400$ $\mathrm{m}^{2}$; and (iii) $>400 \mathrm{~m}^{2}$. The non-parametric Mann-Whitney U-test $(\alpha=0.05)$ was applied to test for differences in the average number of individuals in the different height and gap size classes, using the statistical software SPSS v. 20. Additionally, the Mann-Whitney U-test was used to compare the density of the regeneration layer in the center of the gaps in relation to density occurring closer to gap edges. The percentage of individuals impacted by wild ungulates was also computed.

\section{Results}

\section{Stand structure}

In all examined plots fir still occupied the dominant layer, sometimes with few other conifers (Picea abies (L.) Karst., Pinus nigra Arn., Pinus sylvestris L. and Pseudotsuga menziesii Mirb. Franco). In most plots there was a lower stratum $(\mathrm{DBH}<15 \mathrm{~cm})$ of fir and many different broadleaves: Fagus sylvatica L., Castanea sativa Mill., Acer pseudoplatanus L., Acer opalus Mill., Acer platanoides L., Carpinus betulus L., Ostrya carpinifolia Scop., Quercus cerris L., Prunus avium L., Fraxinus excelsior L., Fraxinus ornus L., Ulmus glabra Huds., Populus tremula L., Sorbus aucuparia L., Tilia cordata Mill., Corylus avellana L., Ilex aquifolium L. Beech and chestnut were by far the most frequent species (Fig. 2).

Significant relationships $(\mathrm{p}<0.01)$ were found between fir stand age and all the examined structural parameters. With increasing age firs from the original plantation showed a general decreasing trend for $\mathrm{N}(\mathrm{r}=-0.30)$, while V $(r=0.50)$ and QMD $(r=0.65)$ showed an increasing trend. Nevertheless, number of trees per hectare, volume per hectare and QMD of fir were very variable within the same age class (Fig. 3), depicting a very diversified situation. QMD had the highest correlation coefficient $(r=0.65)$ probably because it was less influenced by stand density compared to $\mathrm{V} \mathrm{ha}^{-1}$.

The relationship between BA ha ${ }^{-1}$ of the original silver fir component and $\mathrm{BA} \mathrm{ha} \mathrm{H}^{-1}$ of the young firs and broadleaves $(r=-0.58, p$ $<0.01$ ) showed that the density of the regeneration stratum was inversely related to the density of the upper fir layer (Fig. 4).

Number of trees with DBH $>50 \mathrm{~cm}$ varied between 20 and 40 trees per hectare. Number of trees with $\mathrm{DBH}>70 \mathrm{~cm}$ varied between 0 and 16 trees per hectare (Tab. 1).

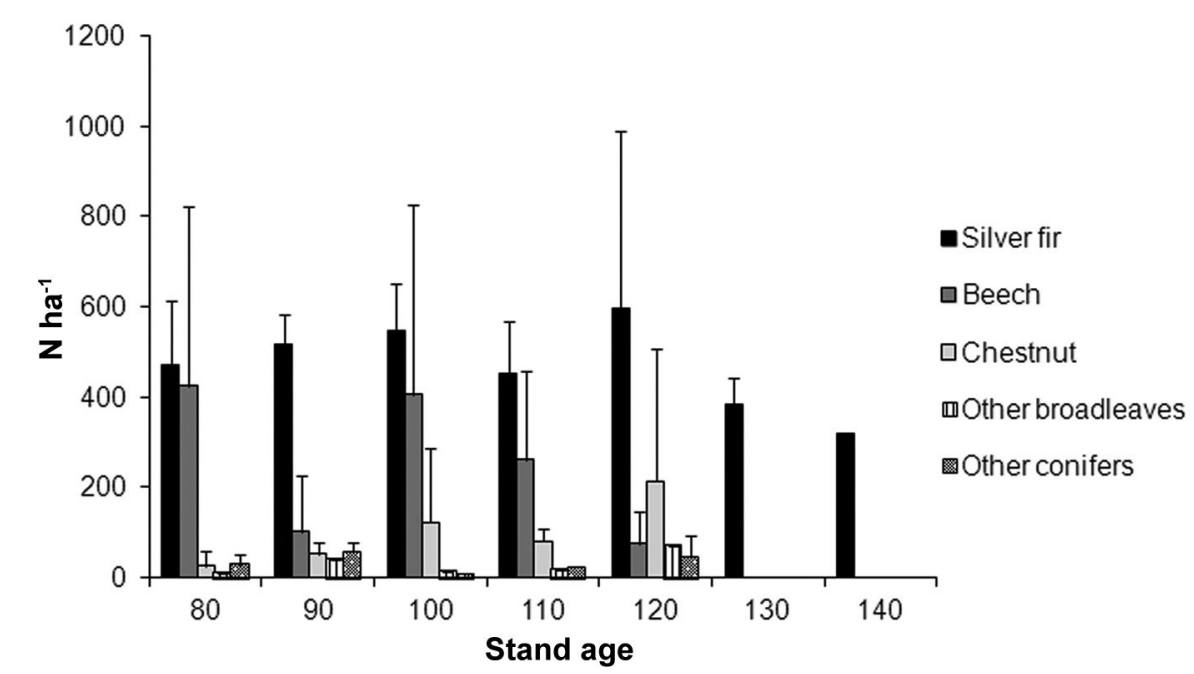

Fig. 2 - Species composition (average number per hectare and standard deviation). 
Fig. 3 - Variation of main stand parameters of the original fir stands with increasing age. (a): number of trees per hectare;

(b): volume per hectare; (c): quadratic mean diameter of trees (QMD).
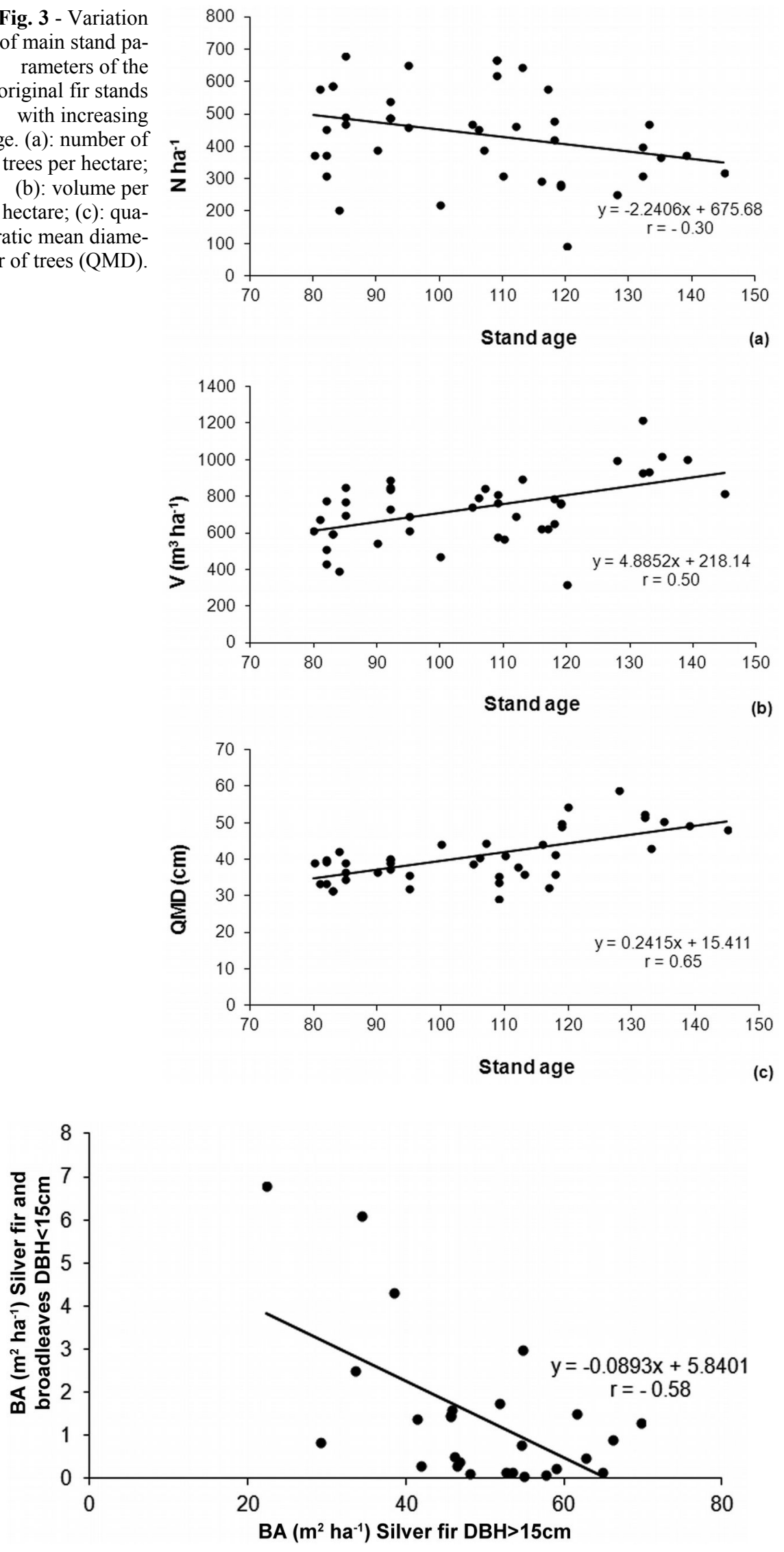

Fig. 4 - Relationship between the basal area (BA) of the original silver fir stands and the ba$\mathrm{sal}$ area of fir and broadleaves in the lower layer $(\mathrm{DBH}<15 \mathrm{~cm})$.
Tab. 1 - Average number per hectare (standard deviation in brackets) of trees with $\mathrm{DBH}>50 \mathrm{~cm}$ and $\mathrm{DBH}>70 \mathrm{~cm}$.

\begin{tabular}{ccc}
\hline Stand age & $\begin{array}{c}\text { DBH }>\mathbf{5 0} \\
\mathbf{c m}\end{array}$ & $\begin{array}{c}\text { DBH }>\text { 70 } \\
\text { cm }\end{array}$ \\
\hline $80-89$ & $20(13)$ & $14(-)$ \\
$90-99$ & $25(20)$ & 0 \\
$100-109$ & $26(20)$ & $16(-)$ \\
$110-119$ & $23(16)$ & $14(8)$ \\
$120-129$ & $21(14)$ & $14(7)$ \\
$130-139$ & $27(26)$ & $10(7)$ \\
$140-149$ & $40(17)$ & 0 \\
\hline
\end{tabular}

\section{Gap dynamics}

From 1983 to 2007 the number of gaps and their total area increased, following the increasing stand age (Tab. 2). Gap fraction was $1.2 \%$ in $1983,1.7 \%$ in 1997 and $2.9 \%$ in 2007.

Most gaps had an area less or equal to 250 $\mathrm{m}^{2}$ in all three surveyed years (Fig. 5); these gaps were $64 \%$ of total number of gaps mapped in 1983, $85 \%$ in 1997 and $67 \%$ in 2007. Small gaps $\left(\leq 250 \mathrm{~m}^{2}\right)$ covered a total of $3477 \mathrm{~m}^{2}$ (28\% of total gap area) in 1983, $11408 \mathrm{~m}^{2}(64 \%)$ in 1997 and $11429 \mathrm{~m}^{2}(38$ $\%)$ in 2007 . The majority of all digitized gaps occurred in stands older than 100 years (Fig. 6).

Between 1983 and 2007 a total of 107 new gaps were formed (total area: $2.4 \mathrm{ha}$ ), 20 gaps were closed (total area: $0.5 \mathrm{ha}$ ) and 21 gaps remained stable (total area: 0.7 ha). In 1997-2007 seven gaps merged (total area: $0.3 \mathrm{ha}$ ) and six gaps were divided (total area: 0.1 ha - Fig. 7).

\section{Natural regeneration}

The average number of seedlings and saplings per hectare in all surveyed gaps was $16110 \pm 16646$ (standard deviation); mean height was $0.7 \pm 2.1 \mathrm{~m}$.

Overall, fir was the dominant species $(>80$ $\%)$ in the regeneration layer, but over $68 \%$ were seedlings and $23 \%$ were in the $<0.5 \mathrm{~m}$ height class. Broadleaves had a smaller number of individuals per hectare, but on avera

Tab. 2 - Number of gaps, mean gap size, total gap area and gap fraction detected in 1983, 1997 and 2007.

\begin{tabular}{|c|c|c|c|}
\hline Characteristics & 1983 & 1997 & 2007 \\
\hline Number of gaps & 39 & 98 & 128 \\
\hline Mean gap size (ha) & 0.03 & 0.02 & 0.02 \\
\hline $\begin{array}{l}\text { Standard deviation of } \\
\text { gap size (ha) }\end{array}$ & 0.03 & 0.02 & 0.02 \\
\hline $\begin{array}{l}\text { Maximum gap size } \\
\text { (ha) }\end{array}$ & 0.11 & 0.18 & 0.12 \\
\hline Total gap area (ha) & 1.24 & 1.79 & 3.02 \\
\hline Gap fraction & 1.2 & 1.7 & 2.9 \\
\hline
\end{tabular}


Fig. 5 - Gap distribution in size classes.

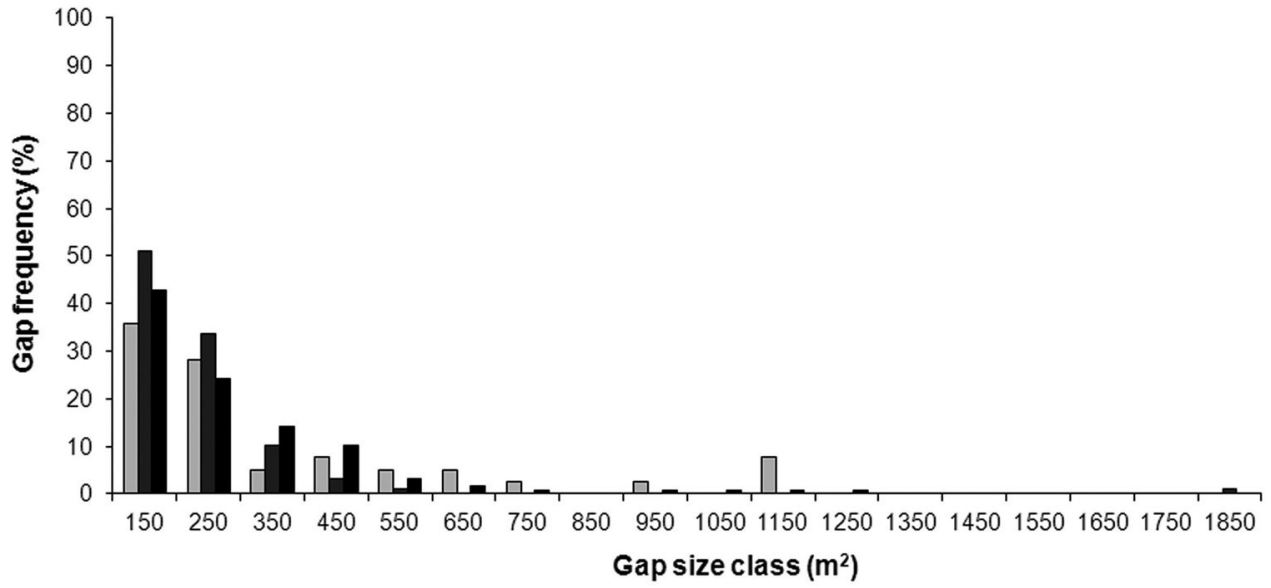

1983

1997

2007

Fig. 6 - Gap distribution in relation to stand age.

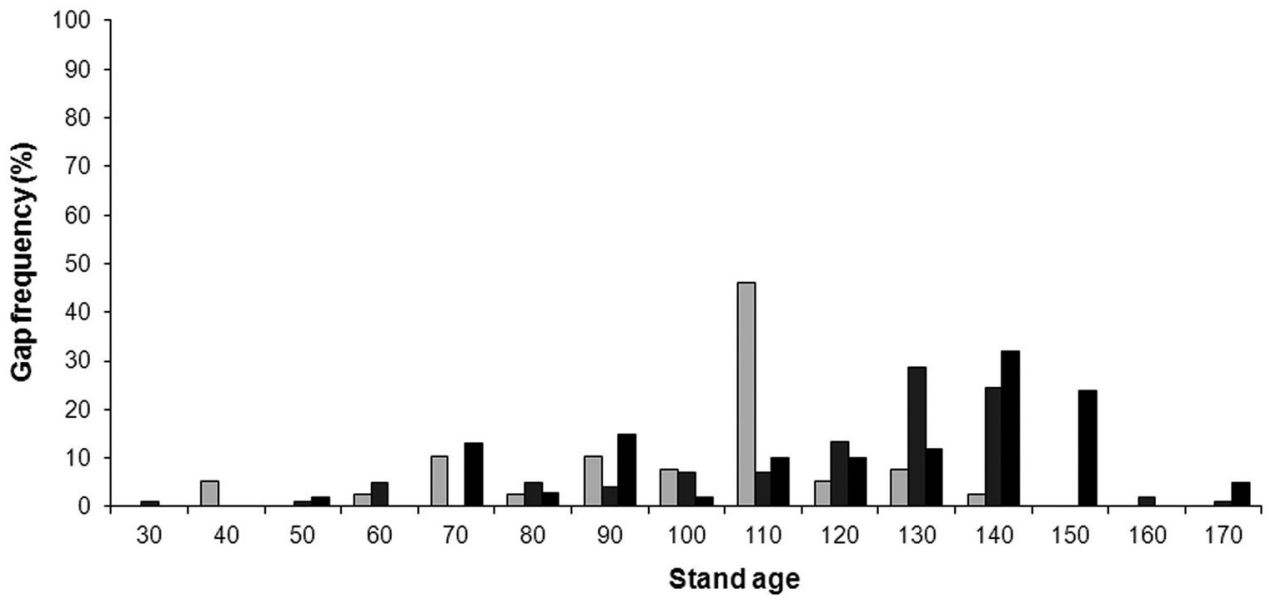

Fig. 7 - Variation of total gap area in the different periods.

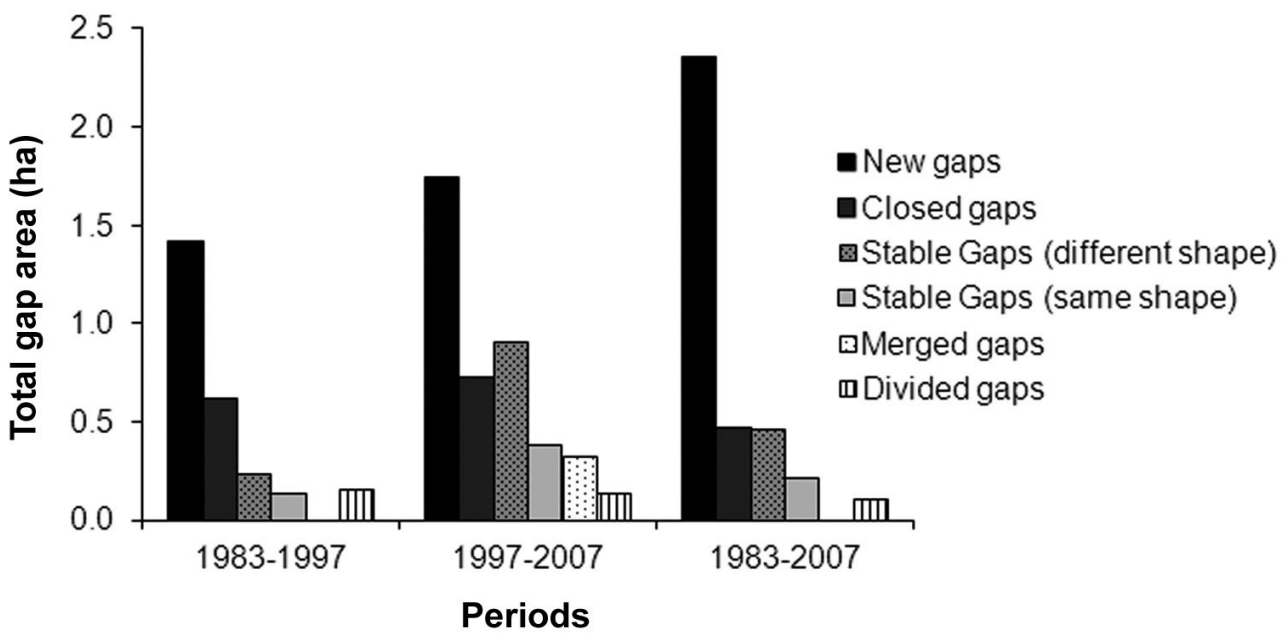

Tab. 3 - Average number of seedlings and saplings per hectare for all surveyed gaps (standard deviation in brackets).

\begin{tabular}{|c|c|c|c|c|c|c|}
\hline Heigth class & Silver fir & Sycamore maple & Beech & Chestnut & Other broadleaves & Other conifers \\
\hline Seedlings & $8833(2330)$ & 1309 (1196) & $9(15)$ & $18(15)$ & $62(41)$ & 0 \\
\hline$<0.5 \mathrm{~m}$ & $2936(1631)$ & $168(77)$ & $141(55)$ & $53(53)$ & $159(70)$ & 0 \\
\hline $0.5-1 \mathrm{~m}$ & $424(46)$ & 0 & $203(41)$ & $18(31)$ & $35(41)$ & $9(15)$ \\
\hline $1-2 m$ & $433(232)$ & $9(15)$ & $80(27)$ & 0 & $27(34)$ & $18(22)$ \\
\hline$>2 \mathrm{~m}$ & $354(110)$ & $176(188)$ & $319(27)$ & $44(55)$ & $230(55)$ & $44(15)$ \\
\hline Total & $12980(3655)$ & $1662(552)$ & $752(118)$ & $133(22)$ & $513(89)$ & $71(18)$ \\
\hline
\end{tabular}




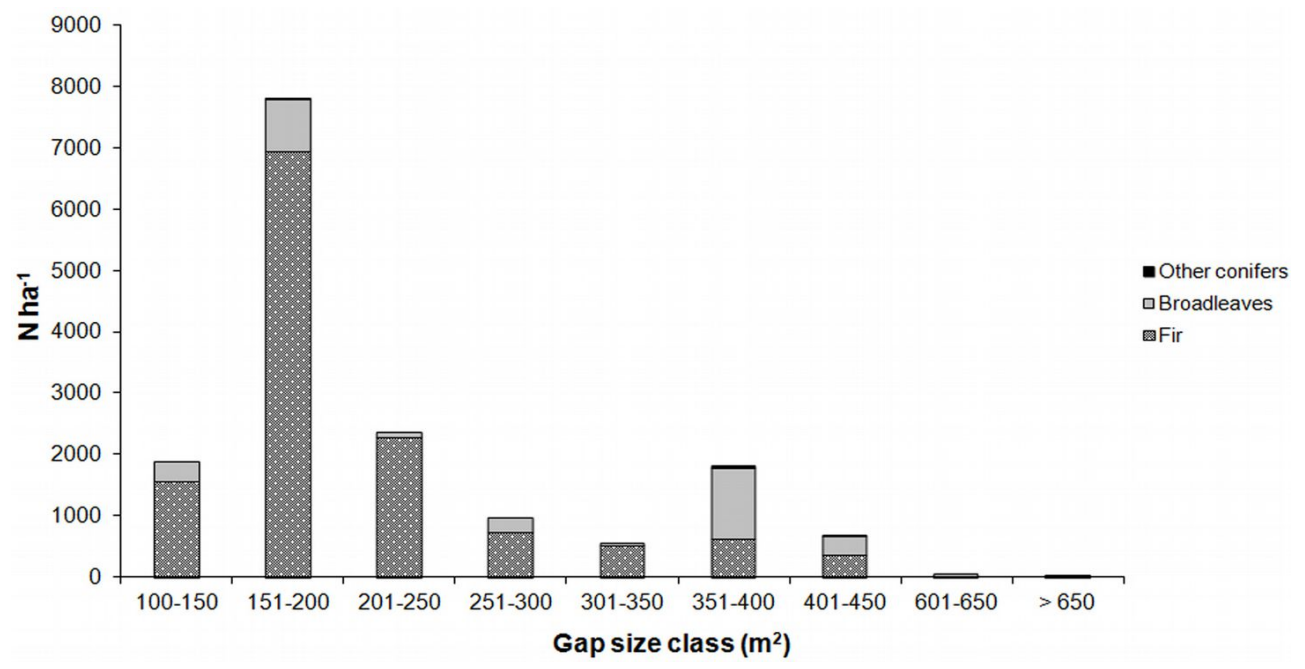

Fig. 8 - Average number per hectare of seedlings and saplings in relation to gap size.

Tab. 4 - Average number of seedlings and saplings per hectare (standard deviation in brackets) in relation to height classes and gap size ( $\mathrm{n}=$ number of surveyed gaps; means with different letters are statistically different $(\alpha \leq 0.05)$ using Mann-Whitney U-test).

\begin{tabular}{|c|c|c|c|c|c|c|c|c|}
\hline $\begin{array}{l}\text { Heigth } \\
\text { class }\end{array}$ & Gap size & All & Silver fir & $\begin{array}{l}\text { Sycamore } \\
\text { maple }\end{array}$ & Beech & Chestnut & $\begin{array}{c}\text { Other } \\
\text { broadleaves }\end{array}$ & $\begin{array}{c}\text { Other } \\
\text { conifers }\end{array}$ \\
\hline \multirow[t]{3}{*}{ Seedlings } & $<200 \mathrm{~m}^{2}(\mathrm{n}=15)$ & $5420(906)$ & $5323^{\mathrm{a}}(905)$ & $71^{a}(100)$ & $0^{\mathrm{a}}$ & $0^{\mathrm{a}}$ & $27^{\mathrm{a}}(-)$ & $0^{\mathrm{a}}$ \\
\hline & $200-400 \mathrm{~m}^{2}(\mathrm{n}=11)$ & $4501(1135)$ & $3395^{\mathrm{ab}}(1427)$ & $1043^{\mathrm{a}}(1191)$ & $9^{a}(19)$ & $18^{\mathrm{a}}(15)$ & $35^{\mathrm{a}}(41)$ & $0^{\mathrm{a}}$ \\
\hline & $>400 \mathrm{~m}^{2}(\mathrm{n}=4)$ & 309 (188) & $115^{\mathrm{b}}(41)$ & $195^{\mathrm{a}}(151)$ & $0^{\mathrm{a}}$ & $0^{\mathrm{a}}$ & $0^{\mathrm{a}}$ & $0^{\mathrm{a}}$ \\
\hline \multirow[t]{3}{*}{$<0.5 \mathrm{~m}$} & $<200 \mathrm{~m}^{2}(\mathrm{n}=15)$ & 2555 (1491) & $2246^{\mathrm{a}}(1410)$ & $106^{\mathrm{a}}(46)$ & $71^{a}(15)$ & $35^{\mathrm{a}}(38)$ & $97^{\mathrm{a}}(100)$ & $0^{\mathrm{a}}$ \\
\hline & $200-400 \mathrm{~m}^{2}(\mathrm{n}=11)$ & $716(227)$ & $557^{\mathrm{b}}(279)$ & $44^{\mathrm{a}}(55)$ & $53^{\mathrm{a}}(27)$ & $18^{\mathrm{a}}(15)$ & $44^{\mathrm{a}}(15)$ & $0^{\mathrm{a}}$ \\
\hline & $>400 \mathrm{~m}^{2}(\mathrm{n}=4)$ & $186(236)$ & $133^{\mathrm{b}}(230)$ & $18^{\mathrm{a}}(15)$ & $18^{\mathrm{a}}(15)$ & $0^{\mathrm{a}}$ & $18^{\mathrm{a}}(31)$ & $0^{\mathrm{a}}$ \\
\hline \multirow[t]{3}{*}{$0.5-1 \mathrm{~m}$} & $<200 \mathrm{~m}^{2}(\mathrm{n}=15)$ & $495(93)$ & $336^{\mathrm{a}}(55)$ & $0^{\mathrm{a}}$ & $124^{\mathrm{a}}(55)$ & $9^{a}(15)$ & $27^{\mathrm{a}}(46)$ & $0^{\mathrm{a}}$ \\
\hline & $200-400 \mathrm{~m}^{2}(\mathrm{n}=11)$ & $115(81)$ & $44^{\mathrm{a}}(41)$ & $0^{\mathrm{a}}$ & $53^{\mathrm{a}}(27)$ & $9^{a}(15)$ & $9^{a}(15)$ & $0^{\mathrm{a}}$ \\
\hline & $>400 \mathrm{~m}^{2}(\mathrm{n}=4)$ & $80(46)$ & $44^{\mathrm{a}}(77)$ & $0^{\mathrm{a}}$ & $27^{\mathrm{a}}(27)$ & $0^{\mathrm{a}}$ & $0^{\mathrm{a}}$ & $9^{\mathrm{a}}(15)$ \\
\hline \multirow[t]{3}{*}{$1-2 \mathrm{~m}$} & $<200 \mathrm{~m}^{2}(\mathrm{n}=15)$ & $469(188)$ & $354^{\mathrm{a}}(173)$ & $9^{a}(15)$ & $80^{\mathrm{a}}(27)$ & $0^{\mathrm{a}}$ & $18^{\mathrm{a}}(31)$ & $9^{\mathrm{a}}(15)$ \\
\hline & $200-400 \mathrm{~m}^{2}(\mathrm{n}=11)$ & $44(41)$ & $35^{\mathrm{a}}(31)$ & $0^{\mathrm{a}}$ & $0^{\mathrm{a}}$ & $0^{\mathrm{a}}$ & $9^{a}(15)$ & $0^{\mathrm{a}}$ \\
\hline & $>400 \mathrm{~m}^{2}(\mathrm{n}=4)$ & $53(70)$ & $44^{\mathrm{a}}(55)$ & $0^{\mathrm{a}}$ & $0^{\mathrm{a}}$ & $0^{\mathrm{a}}$ & $0^{\mathrm{a}}$ & $9^{\mathrm{a}}(15)$ \\
\hline \multirow[t]{3}{*}{$>2 \mathrm{~m}$} & $<200 \mathrm{~m}^{2}(\mathrm{n}=15)$ & $752(201)$ & $239^{a}(116)$ & $150^{\mathrm{a}}(55)$ & $256^{\mathrm{a}}(41)$ & $35^{\mathrm{a}}(31)$ & $62^{\mathrm{a}}(41)$ & $9^{a}(15)$ \\
\hline & $200-400 \mathrm{~m}^{2}(\mathrm{n}=11)$ & $318(46)$ & $88^{\mathrm{a}}(15)$ & $27^{\mathrm{a}}(27)$ & $27^{\mathrm{a}}(46)$ & $9^{a}(15)$ & $133^{\mathrm{a}}(-)$ & $35^{\mathrm{a}}(31)$ \\
\hline & $>400 \mathrm{~m}^{2}(\mathrm{n}=4)$ & $97(31)$ & $27^{\mathrm{a}}(27)$ & $0^{\mathrm{a}}$ & $35^{\mathrm{a}}(38)$ & $0^{\mathrm{a}}$ & $35^{\mathrm{a}}(15)$ & $0^{\mathrm{a}}$ \\
\hline
\end{tabular}

ge $25 \%$ of these were in the $>2 \mathrm{~m}$ height class (Tab. 3).

Most seedlings and saplings grew in gaps $<$ $200 \mathrm{~m}^{2}(15$ gaps out of 30 - Fig. 8). Fir was the prevailing species in most gaps, especially in gaps ranging from 100 to $250 \mathrm{~m}^{2}$.
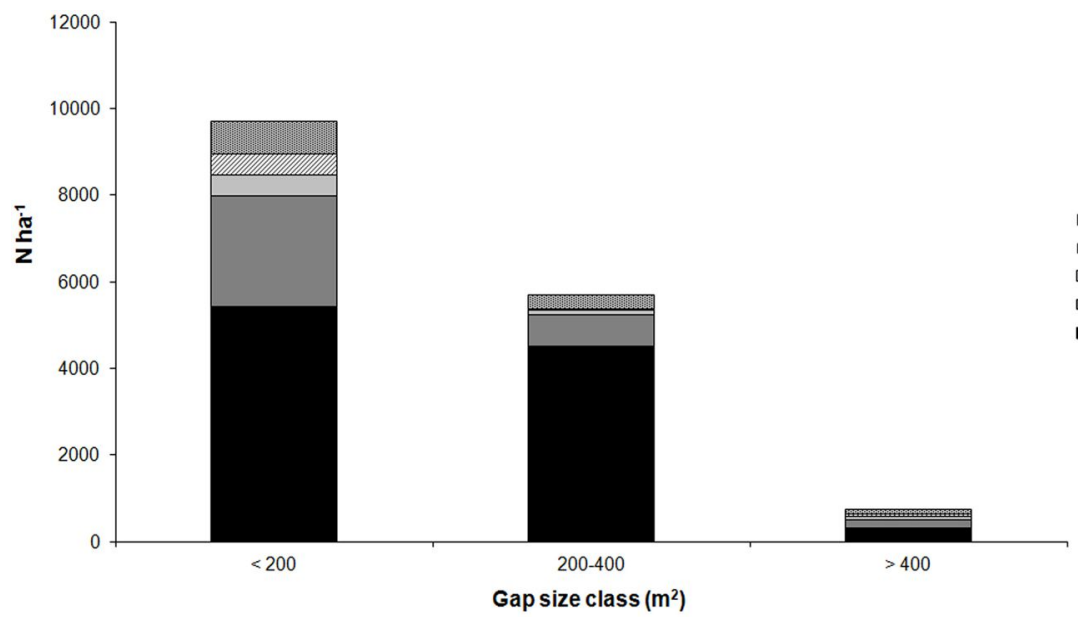

Other broadleaves (beech and sycamore maple) were often associated with fir and they were relatively more abundant in $350-400 \mathrm{~m}^{2}$ gaps (Fig. 8).

Mean number of seedlings and saplings (combined in the five height classes) did not differ significantly (Mann-Whitney U-test) among the three gap size classes $\left(<200 \mathrm{~m}^{2}\right.$, 200-400 $\mathrm{m}^{2}$ and $>400 \mathrm{~m}^{2}$ ), except for fir seedlings and fir $<0.5 \mathrm{~m}$ which were significantly more abundant in the smaller gap size (Tab. 4, Fig. 9).

Fig. 9 - Average number per hectare of seedlings and saplings in relation to gap size and height classes. 
Sycamore maple was more frequent in the seedling stage and in the $<0.5 \mathrm{~m}$ and $>2 \mathrm{~m}$ height classes; seedlings were more abundant in $200-400 \mathrm{~m}^{2}$ gaps. Beech was more abundant in the $>2 \mathrm{~m}$ height class, but did not show differences between the three gap sizes, except for seedlings which concentrated in the 200-400 $\mathrm{m}^{2}$ gaps. Other broadleaves were present in all height classes without clear trends in gap size distribution. Chestnut and other conifers were generally less frequent. The latter were absent in the $<0.5 \mathrm{~m}$ and 0.5-1 $\mathrm{m}$ height classes.

No significant difference (Mann-Whitney U-test) was observed in fir and broadleaves regeneration density between gap centers and gap edges (Fig. 10).

Impact from wild ungulates was most obvious in the $<0.5 \mathrm{~m}$ and $0.5-1 \mathrm{~m}$ height classes, both on fir and broadleaves, where 15 to $75 \%$ of all individuals showed unambiguous signs of grazing. As expected, seedlings were generally not affected, while there was still some damage in the 1-2 $\mathrm{m}$ height class (11 to $33 \%$ ). Based on our data, it was not possible to identify any clear relationship between gap size, tree species and damage intensity.

\section{Discussion}

Structural characteristics and natural regeneration in old-growth stands with fir have been extensively studied in Europe (Dobrowolska \& Veblen 2008, Bottero et al. 2011, Lombardi et al. 2012, Travaglini et al. 2012). Some authors have compared managed stands with stands were active management has stopped for relatively long periods of time, examining the consequences of management cessation on stand structure, composition and old-growth characters (Kuuluvainen et al. 1996, Boncina 2000, Uotila et al. 2001, Motta \& Garbarino 2003, Sitzia et al. 2012).

The aging fir plantations in Vallombrosa have not been managed for over 35 years after traditional rotation age. Following management suspension these plantations have developed some peculiar characteristics: wherever stand density has not diminished after the death of single trees or small groups of trees, fir stands reached a high standing volume (over $1000 \mathrm{~m}^{3} \mathrm{ha}^{-1}$ at age $120+$ ), which alone is not a typical feature of oldgrowth (Barbati et al. 2012); wherever fir density was lower, a layer of trees with DBH $<15 \mathrm{~cm}$ filled in the structure. Fifteen different broadleaved species were recorded in this layer, in varying proportions and usually mixed with fir. This indicates that these stands are evolving towards a mosaic of stands with different age, structure and composition, where fir regeneration alternates with beech and other broadleaves, with patterns similar to those of natural beech-fir forests (Paluch 2007, Vrška et al. 2009).

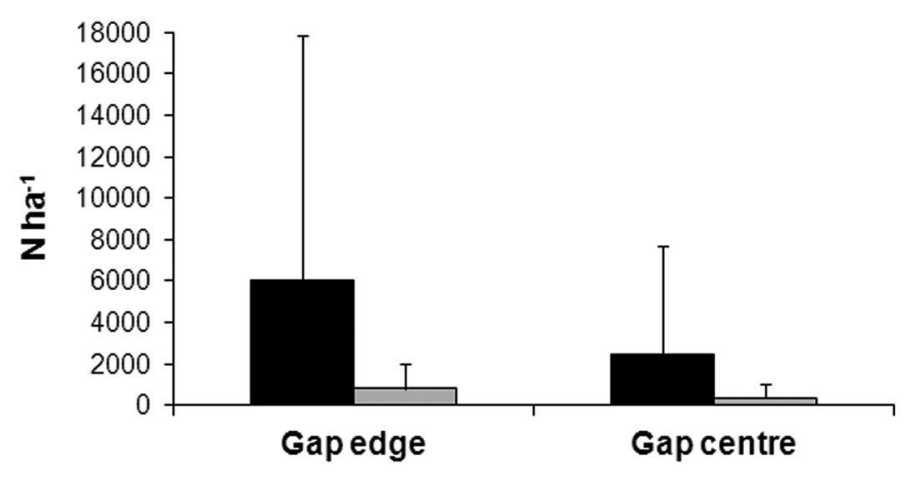

(a)

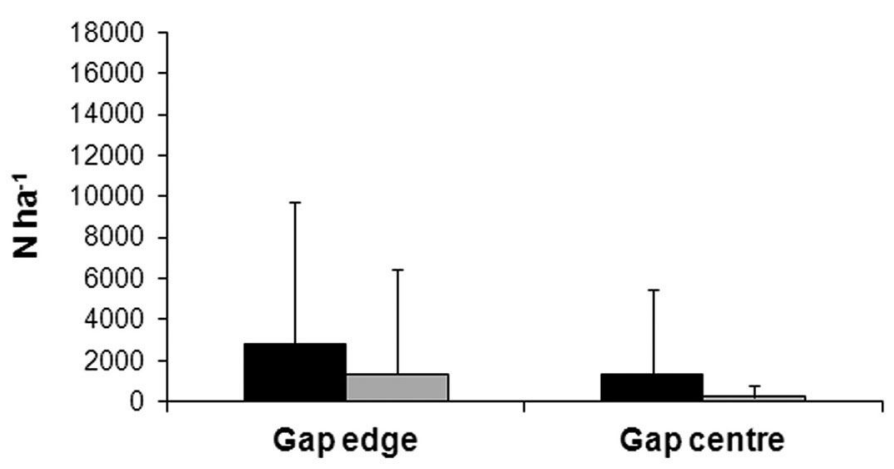

(b)

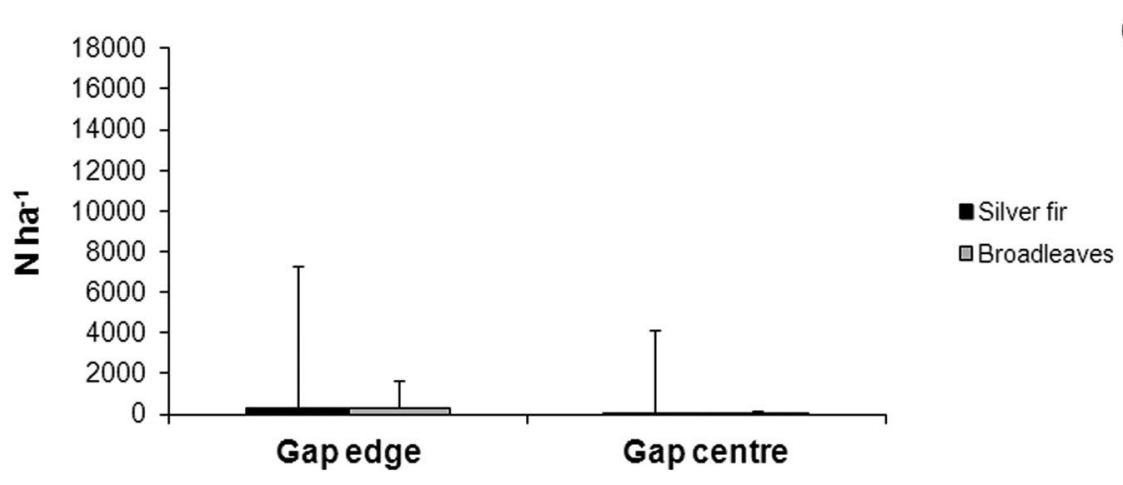

Fig. 10 - Average number per hectare and standard deviation of seedlings and saplings in relation to gap size $\left(<200 \mathrm{~m}^{2}\right.$ (a), 200-400 $\mathrm{m}^{2}$ (b), $>400 \mathrm{~m}^{2}$ (c)) and within-gap position.

On average, the number of large living trees $(\mathrm{DBH}>70 \mathrm{~cm})$ recorded in our survey is about half the density of large living trees reported by Nilsson et al. (2002) in oldgrowth forests in the nemoral forest region of central Europe $\left(30 \mathrm{ha}^{-1}\right)$. Nevertheless, positive effects on biodiversity have already been detected: changes in breeding bird assemblages have been recently reported for this area of the Apennines (e.g., common treecreper, Certhia familiaris; black woodpecker, Dryocopus martius - Suorsa et al. 2005) and attributed to an evident increase in bark feeders directly dependent on the presence of large aging trees (Fantoni 2000, Tellini Florenzano 2004, Martini 2011).

Although these fir stands studied are definitely anthropogenic, gap dynamics is driven by the same mechanism that creates canopy openings in natural temperate forests, i.e., the death of single trees or small groups of trees resulting in fine-scale gap dynamics (Runkle 1982, Veblen 1992, McCarthy 2001, Pham et al. 2004, Dubé et al. 2005, Bobiec 2007, Wagner et al. 2010, Petritan et al. 2013). In particular, the prevalence of small gaps $\left(<250 \mathrm{~m}^{2}\right)$ was similar to gap size reported for mixed old-growth forests with beech and fir (Paci \& Ciampelli 1996, Dobrowolska \& Veblen 2008, Kucbel et al. 2010, Travaglini et al. 2012).

Total gap area was a small percentage (2.9 $\%$ in 2007) of total surveyed area. This value is lower than the gap area generally observed in old-growth forests with fir (Kucbel et al. 2010). For example, in an old-growth forest dominated by beech and silver fir in the Dinaric Mountains of Bosnia and Herzego- 
vina, Nagel \& Svoboda (2008) reported a percentage in canopy gaps ranging from 12 to $17.2 \%$. The gap fraction in Vallombrosa was similar to that $(3.1 \%)$ reported by Dobrowolska \& Veblen (2008) for mixed natural stands with silver fir in the Jata Reserve (Poland), described as stands with structural features corresponding to "optimal and terminal phases of stand development (sensu Leibundgut 1976) in which mature trees are beginning to die and create gaps".

Many studies have focused on the importance of treefall gap openings in determining species compositions and controlling tree regeneration processes (Woods 1984, 2000, Lertzman 1992, Bobiec 2007). Our results showed that gap size had an influence on the total number of seedlings and saplings, but seems to have relatively limited influence on species diversity and on the developmental stage of the regeneration. In our survey, surrounding forest matrix was homogenous for all inventoried gaps, consisting of pure fir stands with very limited presence of broadleaves (mainly beech and sycamore) reaching the dominant layer $(<2 \%$ of the total number of trees). Thus, seed source had a limited influence on species diversity in the regeneration layer. Only young firs (seedlings and fir $<0.5 \mathrm{~m}$ ) appeared to be affected by gap size, being significantly more abundant in gaps $<200 \mathrm{~m}^{2}$. These findings are in accordance with what reported by Albanes et al. (2008), who found that fir seedling density was higher in small $\left(185 \mathrm{~m}^{2}\right)$ than in medium $\left(410 \mathrm{~m}^{2}\right)$ gaps created by cutting trees in a 90-years-old planted silver fir stand in the southern Apennines. However, the apparently limited influence of gap size and position within the gaps on tree species diversity may reflect the relatively small range of gap sizes observed in this study. The sampled gaps were at least 10 years old but interpretation of results must be cautious because time since gap creation can affect both the density of young trees and the relative heights of different tree species.

Our results on wild ungulate impact on natural regeneration was consistent with a previous survey carried out by Casanova et al. (2009) who found that browsing damage to fir regeneration in the Vallombrosa Fores varied between 30 and $95 \%$ of individuals It is well known that young firs are subjected to heavy browsing by wild ungulates (Ammer 1996, Eiberle \& Zehnder 1985, Gill 1992a, 1992b, Motta 1996, Senn \& Suter 2003). Increasing evidence of such impact is being reported in the Alpine region (Motta 1996, Caudullo et al. 2003, Carmignola 2009) but few studies have been carried out in the Apennines. However, despite the outstanding density of wild ungulates in the Vallombrosa Forest, we observed a diffused understory of seedlings and saplings of various species wherever the density of the dominant fir layer was reduced or gaps had opened up. This confirms that natural regeneration is a highly variable process in both space and time, and browsing could be only one of the factors driving seedling establishment and subsequent growth and survival (Senn \& Suter 2003).

\section{Conclusions}

Due to their management history, pure even-aged fir stands beyond their traditional rotation age (100 years) did not exist until recently in the Apennines. Unprecedented dynamics are taking place in these stands, influencing both their future development and their capacity of sustaining important ecosystem services and biodiversity conservation. This is particularly important in the case of the Vallombrosa fir stands for their role as a Natura 2000 site. Our results show that in the last decades a gradual shift from the simplified structure of the fir plantations to stands with diverse and complex structures is taking place. These changes are favoring an increase in the overall biodiversity, in line with the aims of the protected area. However, factors such as increasing wild ungulate pressure, significant changes in climatic parameters and further aging of the remaining fir trees, might contribute in accelerating or shifting this trend towards different outcomes. Thus, these processes must be carefully monitored in order to assess whether the protection goals are being met.

The fact that no active management has been carried out in the forest in the last decades led to a trade-off between wood production, which has decreased, and biodiversity which is increasing. This trade-off could be partly reduced by active management in the younger fir stands $(<80$ years) where moderate thinnings may help in increasing individual fir stability and may favor the natural diffusion of broadleaves and fir regeneration. Furthermore, some small gaps could be opened up artificially in the older fir stands having uniform and dense structures. According to our results, gap size should range between 100 and $200 \mathrm{~m}^{2}$ to favor the natural recruitment of both fir and other species.

Recent changes in management goals have put in a new perspective the natural dynamics taking place in aging, pure even-aged fir stands in the Apennines. These stands are becoming important elements for biodiversity conservation while slowly acquiring a monumental and old-growth character which should be valued and protected.

\section{Acknowledgments}

We wish to thank two anonymous reviewers for their helpful suggestions and comments on an early version of the manuscript.

This study was partially supported by the University of Florence, Fondi di ricerca di Ateneo 2010 "La rinaturalizzazione dei so- prassuoli di abete bianco di origine artificiale in seguito all'applicazione del Piano di Gestione della Riserva Naturale di Vallombrosa (FI)" (Scientific coordinator: Susanna Nocentini).

\section{References}

Albanesi E, Gugliotta OI, Mercurio I, Mercurio R (2008). Effects of gap size and within-gap position on seedlings establishment in silver fir stands. iForest 1: 55-59. - doi: 10.3832/ifor04480010055

Ammer C (1996). Impact of ungulates on structure and dynamics of natural regeneration of mixed mountain forests in the Bavarian Alps. Forest Ecology and Management 88: 43-53. doi: 10.1016/S0378-1127(96)03808-X

Apollonio M, Ciuti S, Pedrotti L, Banti P (2010). Ungulates and their management in Italy. In: "European ungulates and their management in the $21^{\text {th }}$ century" (Apollonio M, Andersen R, Putman R eds). Cambridge University Press, Cambridge, UK, pp. 475-505.

Attiwill PM (1994). The disturbance of forest ecosystems: the ecological basis for conservative management. Forest Ecology and Management 63: 247-309. - doi: 10.1016/0378-1127(94)9011 4-7

Baier P, Meyer J, Gottlein A (2007). Regeneration niches of Norway spruce (Picea abies L. Karst.) saplings in small canopy gaps in mixed mountain forests of the Bavarian Limestone Alps. European Journal of Forest Research 26: 11-22. doi: 10.1007/s10342-005-0091-5

Barbati A, Chirici G, Corona P, Montaghi A, Travaglini D (2009). Area-based assessment of forest standing volume by field measurements and airborne laser scanner data. International Journal of Remote Sensing 30: 5177-5194. - doi: 10.1080/01431160903023017

Barbati A, Salvati R, Ferrari B, Di Santo D, Quatrini A, Portoghesi L, Travaglini D, Iovino F, Nocentini S (2012). Assessing and promoting oldgrowthness of forest stands: lessons from research in Italy. Plant Biosystems 146 (1): 167 174. - doi: 10.1080/11263504.2011.650730

Barzanti GP, Capretti P (1996). Morie nelle abetine del Monte Amiata associate ad Heterobasidion annosum [Silver fir stands mortality caused by Heterobasidion annosum on Mount Amiata]. Monti e Boschi 6: 24-28. [in Italian]

Bianchi L, Paci M (2008). Dynamics and management of silver fir stand in Tuscany: a review of long-term research. Forest@ 5 (1): 122-130. [in Italian with English Abstract] - doi: 10.3832/ efor0517-0050122

Bobiec A (2007). The influence of gaps on tree regeneration: a case study of the mixed lime-hornbeam (Tilio-Carpinetum Tracz. 1962) communities in the Bialowieza a Primeval Forest. Polish Journal of Ecology 55 (3): 441-455.

Bolte A, Czajkowski T, Kompa T (2007). The north-eastern distribution range of European beech - a review. Forestry 80 (4): 413-429. - doi: 10.1093/forestry/cpm028

Boncina A (2000). Comparison of structure and 
biodiversity in the Rajhenav virgin forest remnant and managed forest in the Dinaric region of Slovenia. Global Ecology and Biogeography 9: 201-211. - doi: 10.1046/j.1365-2699.2000.0015 5.x

Bottacci A, Grasso E, Padula M, Radicchi S (2012). Rilievi dendrometrici preparatori al Piano di gestione della Riserva Naturale Biogenetica di Camaldoli [Dendrometric survey for the Management Plan of the Natural Biogenetic Reserve of Camaldoli]. L'Italia Forestale e Montana 67 (4): 317-328. [in Italian] - doi: 10.4129/ifm. 2012.4.01

Bottalico F, Chirici G, Travaglini D (2012). La gestione della foresta di Vallombrosa dal 1876 al 2006. Analisi delle cartografie storiche [The forest management of Vallombrosa from 1876 to 2006: analysis of forest maps]. L'Italia Forestale e Montana 67 (6): 449-458. [in Italian] - doi: 10.4129/ifm.2012.6.01

Bottero A, Garbarino M, Dukić V, Govedar Z, Lingua E, Nagel TA, Motta R (2011). Gap-phase dynamics in the old-growth forest of Lom, Bosnia and Herzegovina. Silva Fennica 45: 875887. - doi: $10.14214 /$ sf.76

Brändli UB (1996). Die häufigsten waldbäume der schweiz. ergebnisse aus dem landesforstinventar 1983-1985: verbreitung, standort und häufigkeit von 30 baumarten. [The commonest forest trees in Switzerland. Findings from the National Forest Inventory 1983-1985: distribution, site and frequency of 30 tree species]. Ber. Eidgenöss. Forschanst. Wald Schnee Landsch. 342: 107-120. [in German]

Brokaw N, Busing RT (2000). Niche versus chance and tree diversity in forest gaps. Trends in Ecology and Evolution 15: 183-188. - doi: 10.1016/S0169-5347(00)01822-X

Busing RT, White PS (1997). Species diversity and small-scale disturbance in an old-growth temperate forest: a consideration of gap-partitioning concepts. Oikos 78: 562-568. - doi: $10.2307 / 3545618$

Canham CD (1989). Different responses to gaps among shade-tolerant tree species. Ecology 70 : 548-550. - doi: 10.2307/1940200

Capretti P (1998). Italy. In: "Heterobasidion annosum: biology, ecology, impact and control" (Woodward S, Stenlid J, Karjalainen R, Hüttermann A eds). CAB International, Wallingford, Oxon, UK, pp. 377-385.

Carmignola G (2009). Il rilievo dell'influsso della fauna selvatica sul bosco nel Parco Nazionale dello Stelvio [Wild ungulates impact on forest regeneration in the Stelvio National Park (Italy)] L'Italia Forestale e Montana 64: 95-108. [in Italian] - doi: 10.4129/IFM.2009.2.04

Casanova P, Memoli A, Pini L (2009). Elementi per la gestione faunistica [Elements for wildlife management]. In: "La Riserva Naturale Statale Biogenetica di Vallombrosa. Piano di Gestione e Silvomuseo: 2006-2025" (Ciancio O ed). Tipografia Coppini, Firenze, Italy. [in Italian] Caudullo G, De Battisti R, Colpi C, Vazzola C, Da Ronch F (2003). Ungulate damage and silviculture in the Cansiglio Forest (Veneto Prealps,
NE Italy). Journal for Nature Conservation 10: 233-241. - doi: 10.1078/1617-1381-00023

Ciancio O, Nocentini S (2006). The conservation of cultural forest landscapes: the Vallombrosa Silvomuseum. In: Proceedings of the "Cultural heritage and sustainable forest management: the role of traditional knowledge" (Parrotta J, Agnoletti M, Johann E eds). Ministerial Conference on the Protection of Forests in Europe, Liason Unit, Warsaw, Poland, vol. 1, pp. 237-242.

Ciancio O, Nocentini S (2011). Biodiversity conservation and systemic silviculture: concepts and applications. Plant Biosystems 145 (2): 411-418. - doi: 10.1080/11263504.2011.558705

Clauser F (1950). Tavola cormometrica per l'abetina di Vallombrosa [Volume table for the Fir wood of Vallombrosa]. L'Italia Forestale e Montana 5 (4): 195-196. [in Italian]

Collins BS, Dunne KP, Pickett STA (1985). Responses of forest herbs to canopy gaps. In: "The ecology of natural disturbance and patch dynamics" (Pickett TA and White PS eds). Academic Press, Orlando, FL,USA, pp. 218-234.

Degen T, Devillez F, Jacquemart AL (2005). Gaps promote plant diversity in beech forests (LuzuloFagetum), North Vosges, France. Annals of Forest Science 62: 429-440. - doi: 10.1051/fo rest:2005039

Denslow JS, Spies T (1990). Canopy gaps in forest ecosystems - an introduction. Canadian Journal of Forest Research 20: 619. - doi: 10. 1139/x90-083

Diaci J (2002). Regeneration dynamics in a Norway spruce plantation on a silver fir-beech forest site in the Slovenian Alps. Forest Ecology and Management 161: 27-38. - doi: 10.1016/S03781127(01)00492-3

Diaci J, Adamic T, Rozman A (2012). Gap recruitment and partitioning in an old-growth beech forest of the Dinaric Mountains: Influences of light regime, herb competition and browsing. Forest Ecology and Management 285: 20-28. - doi: 10.1016/j.foreco.2012.08.010

Dobrowolska D, Veblen T (2008). Treefall-gap structure and regeneration in mixed Abies alba stands in central Poland. Forest Ecology and Management 255: 3469-3476. - doi: 10.1016/j.foreco.2008.02.025

Dubé P, Menard A, Bouchard A, Marceau DJ (2005). Simulating the impact of small-scale extrinsic disturbances over forest volumetric light environment. Ecological modelling 182 (2): 113129. - doi: 10.1016/j.ecolmodel.2004.04.030

Eiberle K, Zehnder U (1985). Kriterien zur Beurteilung des Wildverbisses bei der Weisstanne [Criteria for assessing browsing damage in Silver fir]. Schweizerische Zeitschrift für Forstwesen 136: 399-414. [in German]

Elling W, Dittmar C, Pfaffelmoser K, Rötzer T (2009). Dendroecological assessment of the complex causes of decline and recovery of the growth of fir (Abies alba Mill.) in southern Germany. Forest Ecology and Management 257: 1175-1187. - doi: 10.1016/j.foreco.2008.10.014 Fantoni I (2000). Diffusione del Rampichino alpestre (Certhia familiaris) e relazione con le carat- teristiche stazionali e forestali delle abetine nel Parco Nazionale delle Foreste Casentinesi, Monte Falterona e Campigna [Treecreeper (Certhia familiaris) distribution and relationships with Silver fir stands and site features in the $\mathrm{Ca}$ sentino, Monte Falterona and Campigna Forests National Park]. Bsc thesis, University of Florence, Firenze, Italy, pp. 97. [in Italian]

Farina P, Capretti P, Mugnai L (1990). Gruppi intersterili di Heterobasidion annosum: osservazioni nella foresta di Vallombrosa [Intersterile groups of Heterobasidium annosum: observations in the Vallombrosa Forest]. L'Italia Forestale e Montana 45 (5): 347-360. [in Italian]

Ficko A, Poljanec A, Boncina A (2011). Do changes in spatial distribution, structure and abundance of silver fir (Abies alba Mill.) indicate its decline? Forest Ecology and Management 261: 844-854. - doi: 10.1016/j.foreco.2010.12.014 Gabbrielli A (2000). Le storiche abetine di Vallombrosa [The historical fir stands of Vallombrosa]. L'Italia Forestale e Montana 55 (6): 381385. [in Italian]

Gabbrielli A (2003). Viaggio in Italia sulle tracce dell'abete bianco [Journey in Italy on the trail of Silver fir]. Annali dell'Accademia Italiana di Scienze Forestali 52: 125-207. [in Italian]

Gálhidy L, Mihók B, Hagyó A, Rajkai K, Standovár T (2006). Effects of gap size and associated changes in light and soil moisture on the understorey vegetation of a Hungarian beech forest. Plant Ecology 183: 133-145. - doi: 10.1007/s112 58-005-9012-4

Garbarino M, Mondino EB, Lingua E, Nagel TA, Dukic T, Govedar Z, Motta R (2012). Gap disturbances and regeneration patterns in a Bosnian old-growth forest: a multispectral remote sensing and ground-based approach. Annals of Forest Science 69: 617-625. - doi: 10.1007/s13595-011 -0177-9

Gill RMA (1992a). A review of damage by mammals in north temperate forests. 1. Deer. Forestry 65 (2): 145-169. - doi: 10.1093/forestry/65.2.145 Gill RMA (1992b). A review of damage by mammals in north temperate forests. 3. Impact on trees and forests. Forestry 65: 363-388. - doi: 10.1093/forestry/65.4.363-a

Johann E (2006). Historical development of nature-based forestry in central Europe. In: "Naturebased forestry in Central Europe: alternatives to industrial forestry and strict preservation" (Diaci J ed). Studia Forestalia Slovenica 126, Ljubljana, pp. 1-17.

Johann E (2007). Traditional forest management under the influence of science and industry: the story of the alpine cultural landscapes. Forest Ecology and Management 249: 54-62. - doi: 10. 1016/j.foreco.2007.04.049

Kandler O, Innes JL (1995). Air pollution and forest decline in central Europe. Environmental Pollution 90 (2): 171-180. - doi: 10.1016/0269-7 491(95)00006-D

Kenderes K, Mihók B, Standovár T (2008). Thirty years of gap dynamics in a central European beech forest reserve. Forestry 81 (1): 111-123. doi: 10.1093/forestry/cpn001 
Kint V (2005). Structural development in ageing temperate Scots pine stands. Forest Ecology and Management 214 (1-3): 237-250.

Klimo E, Hager H, Kulhavy J (2000). Spruce monocultures in central Europe. Problems and prospects. EFI Proceedings 33, European Forest Institute, Joensuu, Finland, pp. 208.

Kramer W (1992). Die Weisstanne (Abies alba Mill.) in Ost- und Südosteuropa: Eine Zustandbeschreibung [Description of the situation of Silver fir (Abies alba Mill.) in eastern and southern Europe]. Gustav Fischer Verlag, Stuttgart, Jena, New York, pp. 405. [in German]

Kucbel S, Jaloviar P, Saniga M, Vencurik J, Klimas V (2010). Canopy gaps in an old-growth firbeech forest remnant of Western Carpathians. European Journal of Forest Research 129: 249. 259. - doi: 10.1007/s10342-009-0322-2

Kuuluvainen T, Penttinen A, Leinonen K, Nygren M (1996). Statistical opportunities for comparing stand structural heterogeneity in managed and primeval forests: an example from boreal spruce forest in southern Finland. Silva Fennica 30: 315-328. - doi: 10.14214/sf.a9243

Larsen JB (1986). Das Tannensterb: eine neue Hypothese zur Klärung des Hintergrundes dieser rätselhaften Komplexkrankheit der Weißtanne (Abies alba Mill.) [Fir dieback: a new hypothesis for clarifying the background of this mysterious complex sickness of silver fir (Abies alba Mill.)] Forstwissenschaftliches Centralblatt 105: 381 396. [in German] - doi: 10.1007/BF02741747

Leibundgut H (1976). Die grössten Fichten und Tanen [The largest spruce and fir]. Schweizerische Zeitschrift für Forstwesen 127 (6): 427. [in German]

Lertzman KP (1992). Patterns of gap-phase replacement in a subalpine, old-growth forest. Ecology 73: 657-669. - doi: 10.2307/1940772

Lombardi F, Klopcic M, Di Martino P, Tognetti R, Chirici G, Boncina. A, Marchetti M (2012). Comparison of forest stand structure and management of silver fir-European beech forest type in Central Apennines, Italy and in Dinaric Mountains, Slovenia. Plant Biosystems 144 (1): 114-123. - doi: 10.1080/11263504.2011.623190 Magini E (1967). Ricerche sui fattori della rinnovazione naturale dell'abete bianco sull'Appennino [Research on natural regeneration factors of silver fir in the Apennins]. L'Italia Forestale e Montana 22 (6): 261-270. [in Italian]

Mansourian S, Vallauri D, Dudley N (2005). Forest restoration in landscapes: beyond planting trees. Springer, New York, USA, pp. 437.

Martini I (2011). Composizione e struttura della comunità ornitica nidificante nella Riserva Naturale Statale Biogenetica di Vallombrosa [Composition and structure of bird nesting species in Vallombrosa Biogenetic Natural Reserve]. Bsc Thesis, Faculty of Agronomy, University of Florence, Florence, Italy, pp. 110. [in Italian]

Mattheus U, Ammer U (2000). Conversion of Norway spruce (Picea abies L.) stands into mixed stands with Norway spruce and Beech ( $\mathrm{Fa}$ gus sylvatica L.). Effects on the stand structure in two different test areas. In: "Spruce monocul- tures in Central Europe - Problems and prospects" (Klimo E, Hager H, Kulhavy J eds). EFI Proceedings 33, European Forest Institute, Joensuu, Finland, pp. 71-80.

McCarthy J (2001). Gap dynamics of forest trees: a review with particular attention to boreal forests. Environmental Reviews 9: 1-59. - doi: 10. 1139/a00-012

Motta R (1996). Impact of wild ungulates on forest regeneration and tree composition of mountain forests in the western Italian Alps. Forest Ecology and Management 88 (1-2): 93-98. - doi: 10.1016/S0378-1127(96)03814-5

Motta R, Garbarino F (2003). Stand history and its consequences for the present and future dynamic in two silver fir (Abies alba Mill.) stands in the high Pesio Valley (Piedmont, Italy). Annals of Forest Science 60: 361-370. - doi: 10.10 51/forest:2003027

Mountford EP, Savill PS, Bebber DP (2006). Patterns of regeneration and ground vegetation associated with canopy gaps in a managed beechwood in southern England. Forestry 79: 389-408. - doi: 10.1093/forestry/cpl024

Nagel TA, Svoboda M (2008). Gap disturbance regime in an old-growth Fagus-Abies forest in the Dinaric Mountains, Bosnia-Herzegovina. Canadian Journal of Forest Research 38: 27282737. - doi: 10.1139/X08-110

Niemela T, Korhonen K (1998). Taxonomy of the genus Heterobasidion. In: "Heterobasidion annosum: biology, ecology, impact and control" (Woodward S, Stenlid J, Karvalaines R, Hüttermann A eds). CAB International, Wallingford, Oxon, UK, pp. 27-33.

Nilsson SG, Niklasson M, Hedin J, Aronsson G, Gutowski JM, Linder P, Ljungberg H, Mikusinski G, Ranius T (2002). Densities of large living and dead trees in old-growth temperate and boreal forests. Forest Ecology and Management 161: 189-204. - doi: 10.1016/S0378-1127(01) 00480-7

Nocentini S (2009). Structure and management of beech (Fagus sylvatica L.) forests in Italy. iForest 2: 105-113. - doi: 10.3832/ifor0499-002

Paci M, Ciampelli F (1996). Risposta della vegetazione all'apertura di gap nella Riserva Naturale Integrale di Sasso Fratino [Vegetation response to gap creations in the Sasso Fratino Natural Reserve]. Monti e Boschi 2: 50-58. [in Italian]

Paluch JG (2007). The spatial pattern of a natural European beech (Fagus sylvatica L.)-silver ( $A b i$ es alba Mill.) forest: a patch-mosaic perspective. Forest Ecology and Management 253: 161-170. doi: 10.1016/j.foreco.2007.07.013

PCI (2001). OrthoEngine Reference Manual, Version 8.2 (Oct 2001). PCI Geomatics, Richmond Hill, Ontario, Canada, pp. 184.

Pedersen BS, Howard JL (2004). The influence of canopy gaps on overstory tree and forest growth rates in a mature mixed-age, mixed-species forest. Forest Ecology and Management 196: 351366. - doi: 10.1016/j.foreco.2004.03.031

Peterken GF (1996). Natural woodland. Ecology and conservation in northern temperate regions. Cambridge University Press, Cambridge, UK, pp. 552.

Petritan AM, Nuske RS, Petritan IC, Tudose NC (2013). Gap disturbance patterns in an oldgrowth Sessile oak (Quercus petraea L.) - European beech (Fagus sylvatica L.) forest remnant in the Carpathian Mountains, Romania. Forest Ecology and Management 308: 67-75. - doi: 10.1016/j.foreco.2013.07.045

Pham AT, de Grandpre L, Gauthier S, Bergeron Y (2004). Gap dynamics and replacement patterns in gaps of the northeastern boreal forest of Quebec. Canadian Journal of Forest Research 34: 353-364. - doi: 10.1139/x03-265

Poulson TL, Platt WJ (1989). Gap light regimes influence canopy tree diversity. Ecology 70: 553555. - doi: 10.2307/1940202

Puettmann KJ, Coates KD, Messier C (2009). A critique of silviculture. Managing for complexity. Island Press, Washington, DC, USA, pp. 206.

Rugani T, Diaci J, Hladnik D (2013). Gap dynamics and structure of two old-growth beech forest remnants in Slovenia. PLoS ONE 8 (1) e52641. - doi: 10.1371/journal.pone.0052641

Runkle JR (1982). Patterns of disturbance in some old-growth mesic forests of eastern North-America. Ecology 63: 1533-1546. - doi: 10.2307/193 8878

Runkle JR (1989). Synchrony of regeneration, gaps, and latitudinal differences in tree speciesdiversity. Ecology 70: 546-547. - doi: 10.2307/ 1940199

Runkle JR (1992). Guidelines and sample protocol for sampling forest gaps. General Technical Report PNW-GTR-283, USDA Forest Service, Portland, OR, USA, pp. 44

Seidl R, Fernandes PM, Fonseca TF, Gillet F, Jönsson AM, Merganičová K, Netherer S, Arpaci A, Bontemps JD, Bugmann H, González-Olabarria JR, Lasch P, Meredieu C, Moreira F, Schelhaas MJ, Mohren F (2011). Modelling natural disturbances in forest ecosystems: a review. Ecological Modelling 222: 903-924. - doi: 10.1016/ j.ecolmodel.2010.09.040

Senn J, Suter W (2003). Ungulate browsing on fir (Abies alba Mill.) in the Swiss Alps: beliefs in search of supporting data. Forest Ecology and Management 181: 151-164. - doi: 10.1016/S03 78-1127(03)00129-4

Senni L (1955). L'abete bianco sull'Appennino italiano [Silver fir on Italian Apennines]. In: Proceedings of the "Congresso Nazionale Selvicoltura per il Miglioramento e la Conservazione dei Boschi Italiani". Accademia Italiana di Scienze Forestali, Firenze, Italy, vol. 1, pp. 225 236.

Sitzia T, Trentanovi G, Dainese M, Gobbo G, Lingua E, Sommacal M (2012). Stand structure and plant species diversity in managed and abandoned silver fir mature woodlands. Forest Ecology and Management 270: 232-238. - doi: 10.1016/j.foreco.2012.01.032

Stokland JN, Siitonen J, Jonsson BG (2012). Biodiversity in dead wood. Cambridge University Press, Cambridge, UK, pp. 509.

Suorsa P, Huhta E, Jäntti A, Nikula A, Helle H, 
Kuitunen M, Koivunen V, Hakkarainen $\mathrm{H}$ (2005). Thresholds in selection of breeding habitat by the Eurasian treecreeper (Certhia familiaris). Biological Conservation 121 (3): 443-452. doi: 10.1016/j.biocon.2004.05.014

Tellini Florenzano G (2004). Birds as indicators of recent environmental changes in the Apennines (Foreste Casentinesi National Park, central Italy). Italian Journal of Zoology 71 (4): 317 324. - doi: 10.1080/11250000409356589

Travaglini D, Paffetti D, Bianchi L, Bottacci A, Bottalico F, Giovannini G, Maltoni A, Nocentini S, Vettori C, Calamini G (2012). Characterization, structure and genetic dating of an oldgrowth beech-fir forest in the northern Apennines (Italy). Plant Biosystems 146 (1): 175-188. doi: 10.1080/11263504.2011.650731

Uotila A, Maltamo M, Uuttera J, Isomäki A (2001). Stand structure in seminatural and managed forests in eastern Finland and Russian Karelia. Ecological Bulletins 49: 149-158. [online] URL: http://www.jstor.org/stable/20113272

Vazzano E, Quilghini G, Travaglini D, Nocentini S (2011). Changes in forest cover in the Foresta della Lama (Casentino Forests National Park) from Karl Siemon's and Anton Seeland's 1837 forest management plan. Forest@ 8 (1): 78-87. [in Italian with English abstract] - doi: 10.38 32/efor0655-008

Veblen TT (1992). Regeneration dynamics. In: "Plant succession: theory and prediction" (Glenn-Lewin DC, Peet RK eds). Chapman and Hall, London, UK, pp. 152-187.

Volarik D, Hedl R (2013). Expansion to abandoned agricultural land forms an integral part of silver fir dynamics. Forest Ecology and Management 292: 39-48. - doi: 10.1016/j.foreco.2012.1 2.016

Vrška T, Adam D, Hort L, Kolár T, Janík D (2009). European beech (Fagus sylvatica L.) and silver fir (Abies alba Mill.) rotation in the Carpathians - a developmental cycle or a linear trend induced by man? Forest Ecology and Management 258: 347-356. - doi: 10.1016/j.foreco.2009. 03.007

Wagner S, Collet C, Madsen P, Nakashizuka T, Nyland RD, Sagheb-Talebi K (2010). Beech regeneration research: from ecological to silvicultural aspects. Forest Ecology and Management 259: 2172-2182. - doi: 10.1016/j.foreco.2010.02.
029

Watt AS (1947). Pattern and process in the plant community. The Journal of Ecology 35: 1-22. doi: $10.2307 / 2256497$

Whitmore TC (1989). Canopy gaps and the two major groups of forest trees. Ecology 70: 536538. - doi: 10.2307/1940195

Woods KD (1984). Patterns of tree replacement: canopy effects on understory pattern in hemlocknorthern hardwood forests. Plant Ecology 56: 87107.

Woods KD (2000). Dynamics in late-successional hemlock-hardwood forests over three decades. Ecology 81: 110-126. - doi: 10.1890/0012-9658 (2000)081[0110:DILSHH]2.0.CO;2

Zerbe S (2002). Restoration of natural broadleaved woodland in central Europe on sites with coniferous forest plantations. Forest Ecology and Management 167 (1-3): 27-42. - doi: 10.1016/S0 378-1127(01)00686-7

Zhang K (2008). Identification of gaps in mangrove forests with airborne LIDAR. Remote Sensing of Environment 112: 2309-2325. - doi: 10.1016/j.rse.2007.10.003 